\title{
Pertanggungjawaban Direksi dan Komisaris dalam Kepailitan berdasarkan Prinsip Pierching The Corporate Veil
}

\author{
Mohammad Choirul Anam ${ }^{1}$, Bagas Sukmo Angggoro ${ }^{2}$, Asa Barno Happy Ramadhani ${ }^{3}$, Krista Yitawati ${ }^{4}$ \\ ${ }^{1}$ Mahasiswa Fakultas Hukum, Universitas Merdeka Madiun, Jl. SerayuNo.79, Madiun, 63133 \\ E-mail: - \\ ${ }^{2}$ Mahasiswa Fakultas Hukum, Universitas Merdeka Madiun, Jl. SerayuNo.79, Madiun, 63133 \\ E-mail: - \\ ${ }^{3}$ Mahasiswa Fakultas Hukum, Universitas Merdeka Madiun, Jl. SerayuNo.79, Madiun, 63133 \\ E-mail: - \\ ${ }^{4}$ Fakultas Hukum, Universitas Merdeka Madiun, Jl. SerayuNo.79, Madiun, 63133 \\ E-mail: krista@unmer-madiun.ac.id
}

\begin{abstract}
This study aims to analyze assistance regarding the application of the principle of veil piercing to the Directors and Commissioners of the Company according to Law Number 40 of 2007 concerning Limited Liability Companies for bankruptcy work. This legal research uses juridical normative legal research which is descriptive analytical with a conceptual approach and an invited approach. Legal materials techniques use library research (library research) and are analyzed using qualitative analysis. Based on the results of the research, it shows that the enforcement violates the corporate veil, to protect the rights of shareholders for actions carried out by company organs such as Directors and commissioners who act not in accordance with company objectives. In carrying out their duties, the Board of Directors and commissioners must be based on good faith, caution and a sense of full responsibility towards the company. If the Board of Directors and Commissioners are negligent in carrying out their duties, resulting in the bankruptcy of the company. Directors and Commissioners may be subject to the principle of penetrating the corporate veil, namely personal liability to the personal assets of the Directors and Commissioners for losses incurred by the company and shareholders. This principle is used to protect the interests of the company and shareholders from actions that could harm the company by the Directors and Commissioners.
\end{abstract}

Keywords—: Pierching the Corporate Veil's Principles; Responsibility; Directors; Commissioners; Bankruptcy.

\section{PENDAhUluaN}

Layanan medis baru berupa layanan medis berbasis online pada prinsipnya memberikan pelayanan medis yang dapat dijangkau tanpa perlu tatap muka, sehingga pasien dengan jarak jauh sekalipun dapat menggunakan layanan tersebut. Dari segi penggunaannya, pada layanan medis online menggunakan aplikasi mobile yang ada di smartphone dan untuk mengaksesnya dibutuhkan jaringan internet. Jadi dapat dikatakan layanan medis online lebih mudah diakses dari segi penggunaan juga lebih praktis.

Pemegang Saham dalam suatu PT (perseroan terbatas) memiliki tanggung jawab seperti namanya yaitu terbatas (limited liability), hal ini akan beresiko karena ditanggung hanya sebatas investasi yang ditanamkan dalam saham. Dengan kata lain, Pemegang Saham tidak bertanggungjawab secara pribadi terhadap utang perseroan ${ }^{1}$. Namun, dalam prinsip tanggung jawab hanya terbatas dari Pemegang Saham yaitu pada perseroan terbatas tidak dapat berlaku secara absolut, yang berarti pada keadaan tertentu, Pemegang Saham atau investor dapat mempertanggungjawabkan setiap perbuatannya secara individu atau pribadi. Hal ini dapat dilihat norma yang dapat dilihat pada Pasal 3 ayat 2 Undang-Undang Nomor 40 Tahun 2007 tentang Perseroan Terbatas (selanjutnya disebut UUPT 2007) yang menyatakan:

"Ketentuan sebagaimana dimaksud pada ayat (1) tidak berlaku apabila:

a. Persyaratan perseroan sebagai badan hukum belum atau tidak terpenuhi;

b. Pemegang Saham yang bersangkutan baik langsung maupun tidak langsung dengan itikad buruk memanfaatkan Perseroan untuk kepentingan pribadi;

c. Pemegang Saham yang bersangkutan terlibat dalam perbuatan melawan hukum yang dilakukan oleh Perseroan;

d. Pemegang Saham baik langsung maupun tidak langsung secara melawan hukum menggunakan kekayaan Perseroan, yang mengakibatkan kekayaan Perseroan menjadi tidak cukup untuk melunasi utang Perseroan.”

Ketidakabsolutan atau tidak mutlaknya dari tanggung jawab terbatas Pemegang Saham, sebagaimana yang dimaksud pada Pasal di atas disebut Piercing The Corporate Veil yaitu dalam Bahasa Indonesia berarti "menyingkap tabir atau cadar perseroan".

\footnotetext{
${ }^{1}$ Pasal 3 ayat 1 Undang-Undang Nomor 40 Tahun 2007 tentang Perseroan Terbatas.
} 
Implementasi Piercing The Corporate Veil memiliki tujuan untuk melindungi Pemegang Saham atau investor minoritas atas perbuatan yang dilakukan oleh organ perseroan terbatas seperti Direksi dan Komisaris yang tidak sesuai dengan tujuan dan maksud perseroan terbatas. Direksi adalah salah satu organ dalam perseroan terbatas, yang melakukan semua tindakan dan pengurusan perseroan dan mewakili perseroan, baik di luar maupun dalam pengadilan. Direksi yang mewakili kepengurusan atau kepentingan perseroan terbatas dan menjalankan perseroan terbatas, mempunyai tanggung jawab penuh atas setiap kepengurusan perseroan terbatas. Atas kepengurusan Direksi ini, maka Direksi memiliki tugas dan tanggung jawab.

Komisaris memiliki fungsi, tanggung jawab dan wewenang yaitu secara umum melakukan pengawasan dan menasehati Direksi. Komisaris harus beritikad baik dan penuh dengan tanggung jawab menjalankan kewajiban maupun tugas untuk kepentingan perseroan.

Tanggung jawab Direksi dan Komisaris perseroan terbatas mempunyai tanggung jawab yang sama dengan perusahaannya yang tidak sedang pailit apabila perusahaannya mengalarni kepailitan, pada prinsipnya adalah sama. Direksi dan Komisaris tidak bertanggung jawab secara pribadi terhadap setiap tindakan dan perbuatan yang dilakukan untuk dan atas nama perseroan berdasarkan wewenang yang dimilikinya. Hal ini karena tindakan dan perbuatan Direksi dan Komisaris dilihat sebagai perbuatan perseroan terbatas yang merupakan subjek hukum mandiri jadi perseroan yang bertanggungjawab terhadap setiap tindakan dan perbuatannnya perseroan itu sendiri yang dalam hal ini direpresenstasikan oleh Direksi dan Komisaris. Namun, dalam beberapa hal Direksi dan Komisaris dapat pula dimintai pertanggungjawabannya secara pribadi dalam kepailitan perseroan terbatas ini.

Pasal 1 angka 1 Undang-Undang Nomor 37 Tahun 2004 tentang Kepailitan dan Penundaan Kewajiban Pembayaran Utang (UU Kepailitan), menyebutkan definisi dari kepailitan yaitu: "sita umum atas semua kekayaan debitor pailit yang pengurusan dan pemberesannya dilakukan oleh kurator di bawah pengawasan hakim pengawas sebagaimana diatur dalam undang-undang ini." Kepailitan sebagai putusan pengadilan yang diatur dalam Pasal 1 angka 1 berati bahwa debitor dapat dinyatakan pailit setelah mendapat putusan dari pengadilan yang menyatakan debitor tersebut pailit beserta akibat hukumnya. Kepailitan membawa akibat bahwa Direksi dan Komisaris perseroan tidak berhak, dan berwenang lagi untuk mengurus harta kekayaan ${ }^{2}$. Sesuai dengan sifat badan hukumnya, praktik menunjukkan bahwa perseroan sering digunakan sebagai alat untuk menutupi tanggung jawab yang lebih luas, yang seharusnya dapat dikenakan dan dibebankan terhadap para pihak yang telah menimbulkan kerugian tersebut. Dengan alibi di belakang sifat pertanggungjawaban yang terbatas, seringkali ditemukan keadaan dimana perseroan dijadikan pelindung oleh Direksi dan Komisaris pcrseroan yang tidak memiliki itikad baik. Melalui hal tersebut harta kekayaan Direksi dan Komisaris perseroan yang tidak memiliki itikad baik seolah-olah menjadi tidak tersentuh.

Berdasarkan fenomena tersebut, maka dalam kesempatan kali ini penulis ingin memaparkan sebuah karya tulis yang dilandasi beberapa rumusan masalah sebagai batasan bahasan yang diantaranya sebagai berikut:

1. Bagaimana eksistensi doktrin Piercing The Corporate Veil dalam tata kelola perusahaan?

2. Bagaimana tanggung jawab Direksi dan Komisaris dalam penetapan pailit perseroan terbatas berdasarkan prinsip Piercing The Corporate Veil?

\section{METODE PENELITIAN}

Penelitian hukum ini menggunakan penelitian hukum normatif dimana hukum dikonsepkan sebagai apa yang tertulis dalam peraturan perundang-undangan (law in books) atau hukum dikonsepkan sebagai kaidah atau norma yang merupakan patokan berperilaku manusia yang dianggap pantas. dengan pendekatan perundang-undangan dan pendekatan konseptual. sedangkan menurut jenisnya adalah penelitian terhadap data sekunder. Teknik pengumpulan bahan hukum yang mendukung dan berkaitan dengan pemaparan penulisan hukum ini adalah dengan studi kepustakaan (library researche) dan dianalisis dengan menggunakan analisis kualitatif serta ditafsirkan dengan metode interpretasi sistematis dan interpretasi gramatikal. Data yang digunakan dalam penelitian ini meliputi dua sumber yaitu data primer dan data sekunder. Data primer diperoleh dengan menganalisis peraturan perundang-undangan yang meliputi Undang-Undang Nomor 37 Tahun 2004 tentang Kepailitan dan Penundaan Kewajiban Pembayaran Utang dan Undang-Undang Nomor 40 Tahun 2007 tentang Perseroan Terbatas. Data sekunder diperoleh dari sejumlah keterangan melalui bahan dokumen, literatur, dan hasil penelitian lainnya.

\section{ANALISIS DAN PEMBAHASAN}

\section{A. Eksistensi Doktrin Piercing The Corporate Veil dalam Tata Kelola Perusahaan}

Budaya hukum Indonesia mulai mempengaruhi setiap tindakan pengelolaan perusahaan di Indonesia, yaitu patrimonialism sebagai konsep sosiologi yang dinyatakan Max Weber mengacu pada sistem hubungan patriarki, termasuk dalam konteks sosial, bisnis, dan politik, sehingga berdampak pada pengelolaan perusahaan di Indonesia. ${ }^{3}$

Kedudukan Direksi dan Komisaris pada suatu perseroan terbatas tidak dapat melakukan fungsinya sebagai sebuah institusi lembaga atau badan yang beraktivitas untuk mencari keuntungan ekonomis semata, tetapi juga harus memperhatikan kepentingan stakeholders supaya terlindungi hak-haknya. Direksi berkewajiban melaksanakan tugasnya dengan tidak melampui

\footnotetext{
${ }^{2}$ Ahmad Navis Shahab, 2018, Pertanggungjawaban Hukum Pribadi Pemegang Saham dan Direksi atas Kesalahan Pengurusan yang Mengakibatkan Perseroan Terbatas dinyatakan Pailit, Skripsi, Fakultas Hukum Universitas Sriwijaya, Palembang, hal. 6

${ }^{3}$ Farkhani, 2017, Hukum Perseroan Terbatas (Prinsip Good Corporate Governance dan Doktrin Piercing The Corporate Veil, Iltizam Pustaka, Solo, hal. 9
} 
wewenangnya, sehingga dilakukan pengawasan oleh Dewan Komisaris dan dibatasi Rapat Umum Pemegang Saham (atau yang selanjutnya disebut RUPS). Sebagai pemilik perseroan yang mempunyai ketentuan diatur dalam Undang-Undang Perseroan Terbatas dan Undang-Undang tentang Pasar Modal untuk perusahaan terbuka, dan Anggaran Dasar dari perseroan yang bersangkutan. Adanya perlindungan terhadap hak-hak pemegang saham, persamaan perlakuan pemegang saham, dan fungsi Dewan Komisaris perusahaan serta peranan stakeholders karena lemahnya pelaksanaan pengelolaan perusahaan yang baik di Indonesia berkenaan dengan penegakan hukum (law enforcement). Penyelenggaraan perusahaan yang baik adalah suatu proses dan struktur yang digunakan untuk meningkatkan keberhasilan usaha dan akuntabilitas perusahaan untuk meningkatkan nilai perusahaan (corporate value) dalam jangka panjang dengan memperhatikan kepentingan stakeholders berlandaskan moral, etika, dan peraturan perundang-undangan dibagi 3 (tiga) aktivitas: menerapkan kebijakan nasional, menyempurnakan kerangka regulasi, dan membangun inisiatif sektor swasta. ${ }^{4}$

Pemerintah Republik Indonesia pada tanggal 16 Agustus 2007 telah mengeluarkan Undang-Undang Nomor 40 Tahun 2007 tentang Perseroan Terbatas (selanjutnya disebut UUPT 2007) yang berfungsi untuk mengatur kegiatan suatu perusahaan yang melingkupi aspek organisasi, bisnis, dan budaya perusahaan. ${ }^{5}$

Berdasarkan KEPMEN BUMN No. 117/M- MBU/2002 tanggal 31 Juli 2002 pada pasal 3, prinsip-prinsip yang ada dalam pengelolaan perusahaan yang baik (good corporate governance), yaitu6.

1. Transparansi (transparency), yaitu keterbukaan dalam melaksanakan proses pengambilan keputusan dan keterbukaan dalam mengemukakan informasi materil dan relevan mengenai perusahaan;

2. Kemandirian (independence), yaitu keadaan dimana perusahaan dikelola secara professional tanpa benturan kepentingan dan pengaruh/tekanan dari pihak manapun yang tidak sesuai dengan peraturan perundangan yang berlaku dan prinsipprinsip korporasi yang sehat;

3. Akuntabilitas (accountability), yaitu kejelasan fungsi, pelaksanaan dan pertanggungjawaban organisasi sehingga pengelolaan perusahaan terlaksana secara efektif;

4. Pertanggungjawaban (responsibility), yaitu kesesuaian di dalam pengelolaan perusahaan terhadap peraturan perundangundangan yang berlaku dan prinsip-prinsip korporasi yang sehat;

5. Kewajaran (fairness), yaitu keadilan dan kesetaraan di dalam memenuhi hak-hak stakeholders yang timbul berdasarkan perjanjian dan peraturan perundang-undangan yang berlaku.

Pertanggungjawaban Pemegang Saham, Direksi, dan Komisaris dalam perseroan berbadan hukum pada dasarnya ada batasan dan tidak berlaku mutlak. Hal ini akan timbul terutama apabila sebuah badan hukum dijadikan kendaraan (vehicle) bertujuan dan bermaksud menyimpang dari norma hukum. Oleh karena itu, muncul suatu prinsip yaitu Piercing The Corporate Veil, yang secara sederhana dapat dikatakan bahwa tanggung jawab terbatas Pemegang Saham, Direksi dan atau Komisaris dalam hal-hal tertentu dapat menjadi tidak terbatas.

Doktrin Piercing The Corporate Veil tidak diatur dalam kitab Undang-Undang Hukum Dagang (selanjutnya disebut dengan KUHD), tetapi diatur dalam Undang-Undang Nomor 1 Tahun 1995 tentang Perseroan Terbatas jo UUPT 2007. Doktrin ini mengajarkan bahwa sungguhpun suatu badan hukum bertanggung jawab secara hukum hanya terbatas pada harta badan hukum tersebut, tetapi dalam hal-hal tertentu batas tanggung jawab tersebut dapat ditembus (piercing $)^{7}$.

Prinsip pembatasan penerapan tanggung jawab dari pemegang saham dikenal dengan prinsip Piercing The Corporate Veil. Prinsip ini dalam Bahasa Indonesia selalu diartikan kebenaran menyingkap tabir atau cadar perseroan. Tabir atau cadar yang dimaksud adalah diterobosnya pertanggungjawaban terbatas dari pemegang saham yang ditetapkan dalam Pasal 3 ayat 1 UUPT 2007. Menurut Black's Law Dictionary, sebagaimana dikutip Hassanain Haykal dan Johannes Ibrahim doktrin piercing the corporate veil dijelaskan sebagai berikut ${ }^{8}$ :

"Judicial process whereby court will disregard usual immunity of corporate officers from liability for corporate liabilities; e.g. when incorporation was for sole purpose of perpetrating fraud. The doctrine which holds that the corporate structure with its attended limited liability of stockholders, officers and directors in the case of fraud. The court, however, may look beyond the corporate from only for the defeat of fraud or wrong or the remedying of injustice."

Proses hukum yang dilakukan pengadilan biasanya dengan mengabaikan kekebalan umum pejabat perusahaan atau pihak tertentu perusahaan dari tanggung jawab aktifitas perusahaan: misalnya ketika dalam perusahaan dengan sengaja melakukan kejahatan. Doktrin yang ada berpendapat bahwa struktur perusahaan dengan adanya tanggung jawab terbatas pemegang saham dapat mengabaikan tanggung jawab pemegang saham, pejabat perusahaan dan direktur perusahaan. Pengadilan dalam masalah tersebut akan memandang perusahaan hanya dari sisi kegagalan pembelaan atas tindak kejahatan atau kesalahan atau pemberian sanksi hukuman.

\footnotetext{
${ }^{4}$ Ibid, hal 9

${ }^{5}$ Ibid, hal. 7

${ }^{6}$ Thereza Michiko Labesi, Analisis Penerapan Prinsip-Prinsip Good Corporate Governance di PT. Bank Sulut Kantor Pusat Manado, Jurnal EMBA, Volume 1, Nomor 4, Desember 2013, hal. 1276

${ }^{7}$ Munir Fuady, 2008, Hukum Perusahaan dalam Paradigma Hukum Bisnis: Berdasarkan Undang-Undang Nomor 40 Tahun 2007, Cetakan ke-3, PT Citra Aditya Bakti, Bandung, hal. 65

${ }^{8}$ Hassanain Haykal dan Johannes Ibrahim, Penegakan Hukum dalam Pemaknaan Asas Keadilan dan Penerapan Doktrin Piercing The Corporate Veil dalam hal Timbulnya Kepailitan Perseoran Terbatas, Jurnal Hukum Bisnis, Volume 30, Nomor 3, Tahun 2011, hal. 10
} 
Istilah Piercing The Corporate Veil secara harfiah diartikan mengoyak/menyingkapi tirai/kerudung perusahaan. Sedangkan ilmu hukum, Piercing The Corporate Veil merupakan suatu doktrin atau teori atau ide yang diartikan sebagai suatu bentuk proses untuk membebani tanggung jawab kepada orang atau individu dan perusahaan lain, atas Tindakan hukum yang diperbuat oleh suatu perusahaan pelaku (badan hukum), tanpa melihat fakta bahwa tindakan tersebut dilakukan oleh perseroan pelaku tersebut. Dalam hal ini pengadilan akan mengabaikan status mereka badan hukum dari perusahaan tersebut, lalu memberikan tanggung jawab kepada pihak "organizers" dan "managers" dari perseroan tersebut dengan mengabaikan prinsip tanggung jawab terbatas dari perseroan sebagai badan hukum yang digunakan sebagai tameng atau pelindung oleh mereka. Dalam melakukan perbuatan tersebut bahwa pengadilan telah mengoyak/menyingkapi tirai/kerudung perusahaan (to pierce the corporate veil).

Teori Piercing The Corporate Veil biasanya akan timbul dan diimplementasikan ketika ada kerugian atau tuntutan hukum dari pihak ketiga terhadap perseroan tersebut. Doktrin Piercing The Corporate Veil memiliki tujuan untuk menghindari perbuatan atau hal - hal yang tidak adil terutama bagi pihak luar perseroan dari tindakan penyalahgunaan wewenang atau tidak layak yang dilakukan atas nama perseroan, baik yang timbul dari suatu transaksi dengan pihak ketiga maupun yang muncul dari perbuatan menyesatkan atau perbuatan melawan hukum.

Menurut Munir Fuady beberapa contoh fakta yang secara universal teori Piercing The Corporate Veil ini dapat diterapkan antara lain sebagai berikut ${ }^{9}$ :

1. Permodalan yang tidak layak (terlalu kecil).

2. Penggunaan dana perusahaan secara pribadi.

3. Ketidakadaan formalitas eksistensi perseroan.

4. Terdapatnya elemen-elemen penipuan dengan cara menyalahgunakan badan hukum perseroan.

5. Terjadi transfer modal/asset kepada pemegang saham.

6. Keputusan diambil tanpa memenuhi formalitas tertentu. Misalnya, tidak dilakukannya RUPS untuk kegiatan yang memerlukan RUPS.

7. Sangat dominannya pemegang saham dalam kegiatan perseroan.

8. Tidak diikutinya ketentuan perundang-undangan mengenai kelayakan permodalan dan asuransi.

9. Tidak dipenuhinya formalitas tentang pembukuan dan record keeping. Misalnya terjadi pencampuradukan antara dana milik perseroan dengan dana milik pribadi pemegang saham.

10. Pemilahan badan hukum. Misalnya, untuk menghindari tanggung jawab yang lebih besar karena kemungkinan gugatan dari pihak korban kebakaran, pengusaha taksi membuat perusahaan sendiri-sendiri yang terpisah-pisah untuk setiap taksi yang dimilikinya.

11. Mis-representasi. Misalnya, dibuat kesan kepada kreditor bahwa seolah-olah perusahaan memiliki permodalan yang besar dengan asset yang banyak, mengingat pemegang sahamnya memang memiliki asset yang besar.

12. Perusahaan holding dalam kelompok usaha lebih besar, kecenderungannya untuk dimintakan tanggung jawab hukum atas kegiatan anak perusahaannya ketimbang pemegang saham individu dari perusahaan tunggal.

13. Perseroan tersebut hanya sebagai alter ego (kadang-kadang disebut sebagai instrumentally, dummy atau agent) dari pemegang saham yang bersangkutan.

14. Piercing the corporate veil diterapkan untuk alasan ketertiban umum (openbareorde). Misalnya menggunakan perusahaan untuk melaksanakan hal-hal yang tidak pantas (improper conduct).

15. Piercing the corporate veil diterapkan dalam kasus-kasus kuasi kriminal (quasi criminal). Misalnya jika perusahaan dipergunakan sebagai sarana untuk menjual minuman keras atau untuk perjudian/lotre. Kriteria dasar dan universal agar suatu piercing the corporate veil secara hukum dapat dijatuhkan adalah sebagai berikut:
a. Terjadinya penipuan;
b. Didapatkan suatu ketidakadilan;
c. Terjadinya suatu penindasan (oppression);
d. Tidak memenuhi unsur hukum (illegality);
e. Dominasi pemegang saham yang berlebihan;
f. Perusahaan merupakan alter ego dari pemegang saham mayoritasnya.

\section{B. Tanggung Jawab Direksi dan Komisaris dalam Kepailitan Perseroan Terbatas berdasarkan Prinsip Piercing The Corporate Veil}

Direksi dan Komisaris merupakan organ penting dalam perseroan terbatas selain RUPS. Terkait Direksi, Pasal 1 angka 5 UUPT 2007 menyatakan, bahwa: "Direksi sebagai organ perseroan yang berwenang dan bertanggung jawab penuh atas pengurusan Perseroan untuk kepentingan Perseroan sesuai dengan maksud dan tujuan Perseroan serta mewakili Perseroan, baik di dalam maupun maupun di luar pengadilan sesuai dengan Anggaran Dasar."

Berdasarkan ketentuan lebih lanjut dalam Pasal 92 ayat 1 UUPT 2007 menyatakan, bahwa Direksi memiliki tugas utama, yaitu menjalankan pengurusan perseroan untuk kepentingan perseroan dengan itikad baik dan bertanggung jawab (good faith),

\footnotetext{
${ }^{9}$ Munir Fuady, 2014, Doktrin-Doktrin Modern dalam Corporate Law \& Eksistensinya dalam Hukum Indonesia, Cetakan ke-4, PT. Citra Aditya Bhakti, Bandung, hal. 8
} 
hal ini ditegaskan dalam Pasal 97 ayat 2 UUPT 2007 yang menyatakan bahwa: "Pengurusan sebagaimana dimaksud pada ayat (1), wajib dilaksanakan setiap anggota Direksi dengan itikad baik dan penuh tanggung jawab". Berdasarkan beberapa rumusan dalam UUPT 2007 tersebut, terdapat 2 (dua) kewenangan Direksi, yaitu pengurusan dan perwakilan.

Pengurusan berbicara soal hubungan internal antara pengurus dan orang yang harta berada dalam pengurusan pengurus, maka perwakilan berbicara soal hubungan eksternal, yaitu hubungan antara pengurus dan harta kekayaan yang diurus oleh pengurus tersebut, dengan pihak ketiga, dengan siapa suatu perbuatan hukum dilakukan oleh pengurus dalam kapasitasnya sebagai pengurus harta kekayaan milik orang lain ${ }^{10}$. Oleh karena itu, tanggung jawab Direksi dapat dibedakan ke dalam ${ }^{11}$ :

1. Tanggung jawab internal Direksi, yang meliputi tanggung jawab Direksi terhadap perseroan dan pemegang saham perseroan;

2. Tanggung jawab eksternal Direksi, yang meliputi tanggung jawab Direksi kepada pihak ketiga yang melakukan hubungan hukum, baik langsung maupun tidak langsung dengan perseroan.

Pengurusan perseroan dengan itikad baik dan bertanggungjawab dikenal dengan fiduciary duties. Melalui prinsip tersebut, seorang Direktur memiliki hubungan fidusia dengan perseroan, di mana Direktur tesebut telah mengikatkan diri dengan atau kepada perseroan untuk bertindak dengan itikad baik (bonafide) untuk kemanfaatan atau keuntungan perseroan. Unsur "kepentingan dan tujuan/usaha perseroan" dan "itikad baik dan penuh tanggung jawab "sebagai bagian integral dari pengurusan perseroan oleh Direksi harus dipenuhi secara kumulatif dan alternatif, artinya harus dipenuhi kedua-duanya. Namun demikian, pada kondisi tertentu Direksi dapat menjalankan pengurusan.

Perseroan yang mengalami kepailitan harus ditanggung oleh harta perseroan sebagai Debitor diatur sebagaimana diatur dalam Pasal 21 UU Kepailitan menyebutkan bahwa Kepailitan meliputi seluruh kekayaan debitor pada saat putusan pernyataan pailit diucapkan serta segala sesuatu yang diperoleh selama kepailitan. Penguasaan dan pengelolaan harta debitor diambil alih oleh kurator sampai proses kepailitan selesai dilaksanakan. Penjelasan Pasal 21 UU Kepailitan menjelaskan bahwa "Apabila debitor adalah Perseroan Terbatas, organ perseroan tersebut tetap berfungsi dengan ketentuan jika dalam pelaksanaan fungsi tersebut menyebabkan berkurangnya harta pailit, maka pengeluaran uang yang merupakan bagian harta pailit, adalah wewenang Kurator". Dalam Pasal 24 ayat (1) UU Kepailitan yang menyebutkan bahwa "Kepailitan hanya berlaku pada harta debitor bukan pada diri debitor. Debitor demi hukum kehilangan haknya untuk menguasai dan mengurus kekayaannya yang termasuk dalam harta pailit, sejak tanggal putusan pernyataan pailit diucapkan" lebih lanjut dijelaskan dalam Pasal 26 ayat (1) UU Kepailitan yang menyebutkan bahwa "Apabila ada tuntutan terhadap harta pailit dan berlanjut kepada debitor kemudian berakibat pada hukuman terhadap debitor. Penghukuman tersebut tidak berakibat hukum terhadap harta pailit"..

Namun berdasarkan prinsip Piercing the Corporate Veil, baik Direksi maupun Komisaris harus mempertanggungjawabkan kerugian yang diderita oleh perseroan, apalagi mengakibatkan pailitnya perseroan. Tanggung jawab direksi terhadap kepailitan perseroan dalam hal ini ditegaskan dalam Pasal 97 UUPT 2007:

Pasal 97:

(1) Direksi bertanggung jawab atas pengurusan Perseroan sebagaimana dimaksud dalam Pasal 92 ayat (1).

(2) Pengurusan sebagaimana dimaksud pada ayat (1), wajib dilaksanakan setiap anggota Direksi dengan itikad baik dan penuh tanggung jawab.

(3) Setiap anggota Direksi bertanggung jawab penuh secara pribadi atas kerugian Perseroan apabila yang bersangkutan bersalah atau lalai menjalankan tugasnya sesuai dengan ketentuan sebagaimana dimaksud pada ayat (2).

(4) Dalam hal Direksi terdiri atas 2 (dua) anggota Direksi atau lebih, tanggung jawab sebagaimana dimaksud pada ayat (3) berlaku secara tanggung renteng bagi setiap anggota Direksi.

(5) Anggota Direksi tidak dapat dipertanggungjawabkan atas kerugian sebagaimana dimaksud pada ayat (3) apabila dapat membuktikan:

a. Kerugian tersebut bukan karena kesalahan atau kelalaiannya;

b. Telah melakukan pengurusan dengan itikad baik dan kehati-hatian untuk kepentingan dan sesuai dengan maksud dan tujuan Perseroan;

c. Tidak mempunyai benturan kepentingan baik langsung maupun tidak langsung atas tindakan pengurusan yang mengakibatkan kerugian; dan

d. Telah mengambil tindakan untuk mencegah timbul atau berlanjutnya kerugian tersebut.

(6) Atas nama Perseroan, pemegang saham yang mewakili paling sedikit 1/10 (satu persepuluh) bagian dari jumlah seluruh saham dengan hak suara dapat mengajukan gugatan melalui Pengadilan Negeri terhadap anggota Direksi yang karena kesalahan atau kelalaiannya menimbulkan kerugian pada Perseroan.

(7) Ketentuan sebagaimana dimaksud pada ayat (5) tidak mengurangi hak anggota Direksi lain dan/atau anggota Dewan Komisaris untuk mengajukan gugatan atas nama Perseroan.

Setiap perbuatan yang dilakukan di luar ruang lingkup tujuan yang ditentukan (outside the scope of object clause) dalam Anggaran Dasar Perseroan adalah ultra vires dan batal demi hukum (null and void). Jadi, tindakan Direksi dibatasi oleh tujuan

\footnotetext{
${ }^{10}$ Nur Sa'adah, Tanggung Jawab Pribadi Direksi terhadap Utang Perseroan (Analisis Putusan Mahkamah Agung No: 1914 K/Pdt/2009), Jurnal Surya Kencana Satu: Dinamika Masalah Hukum dan Keadilan, Volume 6, Nomor 2, Tahun 2016, hal. 7

${ }^{11}$ Hassanain Haykal dan Johannes Ibrahim, Op Cit, hal. 16
} 
Perseroan, kapasitas Perseroan mengadakan kontrak atau transaksi maupun sebagai donasi, hanya sebatas tujuan yang ditentukan dalam Anggaran Dasar. Di luar itu, tidak dalam kapasitas Perseroan. Oleh karena itu, tindakan itu dikategorikan sebagai ultra vires dan batal karena hukum (vernietegheid, ipso jure null and void). Sehubungan dengan itu, sesuai dengan doktrin ultra vires ${ }^{12}$ :

1. Perseroan tidak dapat dituntut atas kontrak atau transaksi yang ultra vires

2. Perseroan juga tidak dapat mengukuhkan dan melaksanakannya (to enforce and to perform)

3. RUPS tidak dapat mensahkan akan menyetujui tindakan Direksi yang mengandung ultra vires.

Pengertian ultra vires dalam Dictionary of English Law Beyond the powers. Jadi, berarti tindakan Direksi yang tidak sesuai dengan maksud dan tujuan serta kegiatan usaha, adalah tindakan di luar kekuasaannya (beyond the power). Pengertian yang hampir sama, dikemukakan dalam Merriam Webster's Dictionary of Law. Dikatakan, ultra vires berasal dari latin yang berarti: beyond the power or means, beyond the scope or in execess of legal power or authority. Bertitik dari pengertian yang dijelaskan di atas, doktrin ultra vires dihubungkan dengan Perseroan merupakan permasalahan yang menyangkut dengan transaksi atau kontrak yang dilakukan Direksi dengan pihak ketiga. Pada dasarnya kontrak atau transaksi yang mengandung ultra vires adalah "batal" (nullity) 13 :

1. Perseroan dapat menolak untuk memenuhi kontrak atau transaksi yang mengandung ultra vires;

2. Meskipun pihak ketiga melakukan kontrak atau transaksi dengan good faith hal itu belum mencukupi, karena untuk melindungi pihak ketiga atas kontrak atau transaksi yag mengandung ultra vires, semestinya pihak ketiga itu harus melihat secara konstruktif maksud dan tujuan atau "kapasitas" Perseroan yang tercantum dalam Anggaran Dasar. Hal itu dapat dilakukannya dalam Daftar Perseroan.

Merujuk ketentuan Pasal 97 UUPT 2007, maka setiap anggota Direksi bertanggungjawab atas kerugian Perseroan secara pribadi apabila yang bersangkutan salah atau lalai dalam menjalankan tugasnya. Bentuk tanggung jawab Direksi sebagaimana dimaksud berlaku secara tanggung renteng. Sedangkan bagi Direksi tidak dapat dipertanggungjawabkan atas kerugian, apabila dapat membuktikan:

1. Kerugian tersebut bukan karena kesalahan atau kelalaiannya;

2. Telah melakukan pengurusan dengan itikad baik dan kehati-hatian untuk kepentingan dan sesuai dengan maksud dan tujuan Perseroan;

3. Tidak mempunyai benturan kepentingan baik langsung maupun tidak langsung atas tindakan pengurusan yang mengakibatkan kerugian; dan

4. Telah mengambil tindakan untuk mencegah timbul atau berlanjutnya kerugian tersebut.

Adapun organ Komisaris adalah melakukan pengawasan secara umum dan/atau khusus dan memberikan nasihat kepada Direksi sesuai dengan Pasal 1 butir 6 dan Pasal 108 ayat 1 UUPT 2007 yang menyatakan bahwa "Dewan Komisaris adalah Organ Perseroan yang bertugas melakukan pengawasan secara umum dan/atau khusus sesuai dengan Anggaran Dasar serta memberi nasihat kepada Direksi". Oleh karena itu, wewenang Dewan Komisaris sebagai pengawas dan pemberi nasihat kepada Direksi agar kebijaksanaannya menjalankan pengurusan dan perwakilan perseroan sesuai dengan Anggaran Dasar dalam mencapai kepentingan dan tujuan persero.

Pasal 117 ayat 1 UUPT 2007 memberikan kesempatan bahwa dalam anggaran dasar dapat ditetapkan pemberian wewenang kepada Dewan Komisaris untuk memberikan persetujuan/bantuan kepada direksi dalam melakukan perbuatan hukum tertentu untuk mengefektifkan pengawasan terhadap Direksi. Apabila dalam Anggaran Dasar menetapkan persyaratan perlunya persetujuan/bantuan atas perbuatan hukum tersebut, kemudian Direksi melakukan perbuatan hukum tersebut tanpa persetujuan/bantuan Dewan Komisaris, maka perbuatan hukum tersebut tetap mengikat perseroan sepanjang pihak lainnya dalam perbuatan hukum tersebut beritikad baik. Apabila perbuatan hukum tersebut ternyata merugikan perseroan, maka Direksi wajib bertanggung jawab secara pribadi.

Pemberian wewenang kepada Dewan Komisaris terutama dalam hal ini Direksi melakukan perbuatan hukum dengan pihak ketiga seperti melakukan perjanjian utang piutang dengan pihak ketiga yang membebankan aset perseroan. Berdasarkan ketentuan dalam Anggaran Dasar atau keputusan RUPS, Komisaris juga berwenang untuk melakukan tindakan pengurusan perseroan dalam keadaan tertentu untuk jangka waktu tertentu (Pasal 118 ayat (2) UUPT 2007). Jika fungsi Direksi digantikan oleh Dewan Komisaris dalam melakukan pengurusan perseroan tersebut, maka semua ketentuan mengenai hak, wewenang, dan kewajiban Direksi terhadap perseroan dan pihak ketiga berlaku juga bagi Komisaris yang melaksanakan fungsi Direksi.

Pasal 114 ayat 1 UUPT 2007 secara tegas menentukan bahwa Dewan Komisaris bertanggung jawab atas pengawasan perseroan. Setiap anggota Dewan Komisaris wajib dengan beritikad baik, kehatihatian, dan bertanggung jawab dalam menjalankan tugas pengawasan dan pemberian nasihat kepada Direksi untuk kepentingan perseroan dan sesuai dengan maksud dan tujuan Perseroan. Setiap anggota Dewan Komisaris ikut bertanggung jawab secara pribadi atas kerugian Perseroan apabila yang bersangkutan bersalah/lalai dalam menjalankan tugasnya. Pasal 114 secara tegas menyatakan:

Pasal 114:

(1) Dewan Komisaris bertanggung jawab atas pengawasan Perseroan sebagaimana dimaksud dalam Pasal 108 ayat (1).

\footnotetext{
${ }^{12}$ M. Yahya Harahap, 2009, Hukum Perseroan Terbatas, Jakarta, Sinar Grafika, hal 67

${ }^{13} \mathrm{Ibid}$
} 
Website : http://yustisia.unmermadiun.ac.id/index.php/yustisia

(2) Setiap anggota Dewan Komisaris wajib dengan itikad baik, kehatihatian, dan bertanggung jawab dalam menjalankan tugas pengawasan dan pemberian nasihat kepada Direksi sebagaimana dimaksud dalam Pasal 108 ayat (1) untuk kepentingan Perseroan dan sesuai dengan maksud dan tujuan Perseroan.

(3) Setiap anggota Dewan Komisaris ikut bertanggung jawab secara pribadi atas kerugian Perseroan apabila yang bersangkutan bersalah atau lalai menjalankan tugasnya sebagaimana dimaksud pada ayat (2).

(4) Dalam hal Dewan Komisaris terdiri atas 2 (dua) anggota Dewan Komisaris atau lebih, tanggung jawab sebagaimana dimaksud pada ayat (3) berlaku secara tanggung renteng bagi setiap anggota Dewan Komisaris.

(5) Anggota Dewan Komisaris tidak dapat dipertanggungjawabkan atas kerugian sebagaimana dimaksud pada ayat (3) apabila dapat membuktikan:

a) Telah melakukan pengawasan dengan itikad baik dan kehati- hatian untuk kepentingan Perseroan dan sesuai dengan maksud dan tujuan Perseroan;

b) Tidak mempunyai kepentingan pribadi baik langsung maupun tidak langsung atas tindakan pengurusan Direksi yang mengakibatkan kerugian; dan

c) Telah memberikan nasihat kepada Direksi untuk mencegah timbul atau berlanjutnya kerugian tersebut.

5. Atas nama Perseroan, pemegang saham yang mewakili paling sedikit $1 / 10$ (satu persepuluh) bagian dari jumlah seluruh saham dengan hak suara dapat menggugat anggota Dewan Komisaris yang karena kesalahan atau kelalaiannya menimbulkan kerugian pada Perseroan ke Pengadilan Negeri.

Pada prinsipnya pertanggungjawaban secara pribadi dari Direksi dan Komisaris ketika bertindak di luar maksud dan tujuan perseroan, khususnya dalam Kepailitan merupakan salah satu bentuk penegakan keadilan dalam ranah hukum privat. Hal ini bertujuan agar Direksi dan Komisaris dapat menjalankan pengurusan dan pengawasan secara baik, seksama, dan penuh integritas, sehingga penyalahgunaan wewenang dapat diminimalisasi. Di samping itu, dengan penerapan prinsip Piercing the Corporate Veil, perseroan terbatas tidak lagi dijadikan sarana untuk mengeksplorasi kepentingan maupun keuntungan pribadi.

\section{IV.KESIMPULAN DAN SARAN}

1. Eksistensi Doktrin Piercing The Corporate Veil dalam Tata Kelola Perusahaan adalah untuk melindungi Pemegang Saham Minoritas atas tindakan yang dilakukan oleh organ perseroan terbatas seperti Direksi dan Komisaris, yang tidak sesuai dengan maksud dan tujuan perseroan. Direksi yang merupakan salah satu organ dalam perseroan terbatas, yang melakukan semua kegiatan perseroan dan mewakili perseroan, baik di dalam maupun di luar pengadilan. Direksi yang mewakili kepentingan perseroan terbatas dan menjalankan perseroan terbatas, bertanggung jawab penuh atas kepengurusan perseroan terbatas. Komisaris memiliki tanggung jawab atas kewenanganya dalam melakukan pengawasan dan menasehati Direksi. Komisaris wajib beritikad baik dan penuh tanggungjawab menjalankan tugas untuk kepentingan dan usaha perseroan.

2. Tanggung Jawab Direksi dan Komisaris dalam Kepailitan Perseroan Terbatas berdasarkan Prinsip Piercing The Corporate Veil adalah dengan bertanggungjawab atas kerugian Perseroan secara pribadi apabila yang bersangkutan salah atau lalai dalam menjalankan tugasnya, apalagi mengakibatkan pailitnya perseroan apabila terbukti bertindak di luar maksud dan tujuan perseroan.

\section{DAFTAR PUSTAKA}

\section{A. Buku}

Farkhani, 2017, "Hukum Perseroan Terbatas (Prinsip Good Corporate Governance dan Doktrin Piercing The Corporate Veil", Solo, Iltizam Pustaka Fuady, M, 2008, "Hukum Perusahaan dalam Paradigma Hukum Bisnis: Berdasarkan Undang-Undang Nomor 40 Tahun 2007”, Bandung, PT Citra Aditya Bakti Harahap, M. Y, 2009, "Hukum Perseroan Terbatas" Jakarta: Sinar Grafika

Shahab, A. N., Syaifuddin, M., \& Novera, A, 2018, "Pertanggungjawaban Hukum Pribadi Pemegang Saham dan Direksi atas Kesalahan Pengurusan yang Mengakibatkan Perseroan Terbatas Dinyatakan Pailit”, Doctoral Dissertation, Sriwijaya University

\section{B. Jurnal}

Labesi, T. M. (2013). Analisis Penerapan Prinsip-Prinsip Good Corporate Governance di PT Bank Sulut Kantor Pusat Manado. Jurnal EMBA: Jurnal Riset Ekonomi, Manajemen, Bisnis dan Akuntansi, 1(4)

Sa'adah, N. (2017). Tanggung Jawab Pribadi Direksi Terhadap Utang Perseroan (Analisis Putusan Mahkamah Agung No: 1914 K/Pdt/2009). Jurnal Surya Kencana Satu: Dinamika Masalah Hukum dan Keadilan, 6(2), 1-18

\section{Peraturan Perundang-undangan}

Undang-Undang Nomor 40 Tahun 2007 tentang Perseroan Terbatas 